\title{
THE CONTESTABILITY OF AIRLINE MARKETS DURING THE TRANSITION TO DEREGULATION*
}

\author{
Elizabeth E. Bailey \\ John C. Panzar $\dagger$
}

INTRODUCTION

The theory of contestable markets has been developed to analyze the equilibrium properties of markets that may have economies of scale but that are characterized by perfectly free and easy entry and exit. In a recent series of papers, Panzar and Willig, ${ }^{1}$ Baumol, Bailey, and Willig, ${ }^{2}$ and Baumol and Willig ${ }^{3}$ have shown that contestable markets, even if actually served by only one firm, exhibit many of the desirable properties of competitive markets in the sense that a weak version of Adam Smith's invisible hand holds sway.

In this article we argue that this theory is particularly relevant to city-pair airline markets. Many thin city-pair markets have natural monopoly characteristics, and even those that do not have become readily contested with the demise of restrictive licensing. For most markets, carriers exist with appropriately-sized aircraft and with facilities at one or both end points who could enter. Pricing evidence that accumulated since deregulation is consistent with the premise that medium and long-haul routes served by local service carriers were nearly perfectly contestable in late 1979 and early 1980. In these markets, potential competition by trunk carriers has effectively policed the pricing behavior of the local carriers. The city-pair markets that are primarily served by trunk carriers have been readily contested in the sense that new entry has abounded. However, these markets have not been perfectly contestable since actual competition has brought price changes.

\section{Scale Economies, Entry Barriers, and Sunk Costs}

In this Section, we attempt to reconcile the apparent contradiction between the (casual) empirical observation that many, if not most, city-pair airline markets are in

\footnotetext{
* Copyright 1981 by Duke University.

†The authors are, respectively, Member, Civil Aeronautics Board and Head, Economic Analysis Research Department, Bell Laboratories. The authors are grateful to Bob Frank, Dan Kaplan, Ted Keeler, Mike Levine, Roy Pulsifer and Bob Willig for their helpful insights. Wayne Watkins of the CAB staff supplied much of the data. The opinions expressed in this paper are those of the authors and do not necessarily reflect official policy or views of either the Civil Aeronautics Board, Bell Laboratories, or the Bell System.

1. Panzar \& Willig, Free Entry and the Sustainability of Natural Monopoly, 8 BEL.L. J. Ecox. 1 (1977).

2. Baumol, Bailey \& Willig, Weak Invisible Hand Theorems on the Sustainability of Prices in a Multiproduct Monopoly, 67:3 Am. Econ. ReV. 350 (1977).

3. Baumol \& Willig, Fixed Costs, Sunk Costs, Entry Barriers, Public Goods, and the Sustainability of Monopoly, Princeton University Discussion Paper (1979) [hereinafter cited as Baumol \& Willig]
} 
some sense natural monopolies and the almost universal acceptance of the view that there is no need to regulate them. While the latter phenomenon requires little elaboration or support, the pervasiveness of natural monopoly requires some, at least heuristic, documentation. After sketching an, admittedly, devil's advocate version of that case, we shall go on to argue that the presence of technological natural monopolies in thin city-pair markets in no way reduces the desirability of deregulation.

Going back (at least) to Caves' ${ }^{\prime 4}$ industry study, economists have come to accept the conclusion that there are no significant economies of scale in air transport. However, the evidence adduced directly addresses the issue of system rather than city-pair market economies of scale. ${ }^{\tilde{z}}$ Unfortunately, the assurance that large trunk airline systems may enjoy no significant unit cost advantage over the smaller trunks provides no information as to whether or not there are substantial economies of scale in serving an individual city-pair market. An econometric analysis of returns to scale at the market level would face seemingly insurmountable difficulties in measuring and allocating common costs to individual markets. To our knowledge, no convincing study of that sort has been done.

It is possible, however, to offer some plausible, if less quantitative, arguments in support of economies of scale at the market level. It is well-known that there are substantial economies of scale with respect to aircraft size. That is, costs per seat decline dramatically the larger the aircraft. Table I provides a crude illustration of these scale economies for three representative stage lengths. For example, in

TABLE I

Economies of Aircraft Size

\begin{tabular}{|c|c|c|c|c|c|}
\hline $\begin{array}{l}\text { Stage } \\
\text { Length }\end{array}$ & Aircarft & Seats* & $\begin{array}{c}\text { Average } \\
\text { Cost Per } \\
\text { Passenger** }\end{array}$ & $\begin{array}{c}\text { Total Segment } \\
\text { Cost** }\end{array}$ & $\begin{array}{c}\text { Marginal } \\
\text { Cost Per } \\
\text { Additional } \\
\text { Passenger** }\end{array}$ \\
\hline $\begin{array}{l}500 \\
\text { Miles }\end{array}$ & $\begin{array}{l}\text { CV }-580 \\
\text { B-737-200 }\end{array}$ & $\begin{array}{r}56 \\
130\end{array}$ & $\begin{array}{ll}\$ & 61 \\
\$ & 42\end{array}$ & $\begin{array}{l}\$ 2,562 \\
\$ 4,095\end{array}$ & $\overline{\$ 28.62}$ \\
\hline $\begin{array}{l}1,000 \\
\text { Miles }\end{array}$ & $\begin{array}{l}\text { B-737-200 } \\
\text { B-727-200 }\end{array}$ & $\begin{array}{l}130 \\
162\end{array}$ & $\begin{array}{l}\$ 64 \\
\$ 58\end{array}$ & $\begin{array}{l}\$ 6,240 \\
\$ 7,047\end{array}$ & $\$ \overline{\$ 4.63}$ \\
\hline $\begin{array}{l}1,500 \\
\text { Miles }\end{array}$ & $\begin{array}{l}\text { B- } 727-200 \\
\text { DC- } 10-10\end{array}$ & $\begin{array}{l}162 \\
380\end{array}$ & $\begin{array}{l}\$ 81 \\
\$ 69\end{array}$ & $\begin{array}{l}\$ 9,842 \\
\$ 19,665\end{array}$ & $\$ \overline{51.85}$ \\
\hline
\end{tabular}

Source: Robert Frank, Is the Current Airfare Structure Discriminatory?, Internal CAB Memorandum V0062, January 1980, Table I.

4. R. Caves, Air Transport and its Regllators (1962).

5. Keeler, Domestic Trunk Airline Regulation: An Economic Evaluation, in Senate Comm. on Gov't Aff., 95th Cong. 2d Sess., Strdiy ox Federal. Regillation. App. To Vol.. VI. Framework for Regulation (1978) provides the broadest and most readily accessible discussion of research in this area up to the eve of deregulation. On the issue of scale economies, see his discussion on pages $107-11$ and the references cited therein [hereinafter cited as keeler]. 
moving from a B-727-200 to a DC-10-10 on a 1,500 mile segment, an additional 163 passengers can be carried at a 75 percent load factor at a cost of about $\$ 52$ per additional passenger, some 36 percent less than the average cost per passenger in the B-727-200. This argues for a relatively small equilibrium number of (turnaround) flights per day in many of the markets flown today. Thus, if declining average costs per flight pertain up to, say, a few flights per day, a substantial portion of the nation's city-pair markets would be natural monopolies in this dimension. If we assume that load factors are relatively constant, this also means that average costs per passenger fall over the relevant range in many markets. ${ }^{6}$

This heuristic line of reasoning is supported by evidence that even today, after nearly two years of liberalized entry policy, most of the trunk and local service carrier city-pair markets in the United States are served by only one firm. Indeed, Table II displays the number of nonstop markets in the United States which were flown by one or more of the trunk and local service carriers as of January 1, 1980. Of the 1,686 nonstop routes, some 1,161 were served by only one carrier. Thus, some 69.4 percent of domestic nonstop routes are monopolies. ${ }^{7}$ As additional inferential evidence, it should be noted that the unregulated commuter air carrier industry consists predominantly of single carrier markets.

TABLE II

Nonstop Markets in the Domestic United States for Trunk and Local Service Carriers JANUARY 1, 1980

\begin{tabular}{lcc}
\hline & $\begin{array}{c}\text { Number of } \\
\text { Monopoly Markets }\end{array}$ & $\begin{array}{c}\text { Number of } \\
\text { Competitive Markets }\end{array}$ \\
$0-200$ miles & 425 & 111 \\
$201-400$ miles & 294 & 106 \\
$401-600$ miles & 140 & 78 \\
601 plus & 302 & 230 \\
\hline
\end{tabular}

Source: CAB Analysis of Official Airline Guide data.

Assuming then that declining unit costs are an important fact of life in many, if not most city-pair markets, why does this not lead to policy problems similar to those encountered with traditional, regulated natural monopolies such as public utilities?

Our answer to this question is, in essence, little different from that provided by Keeler and others. ${ }^{8}$ However, in explicitly raising the issue of city-pair market

6. The above discussion ignores the countervailing forces created by the desire of different passengers to fly at different times during the day and the fact that, in general, load factors will not remain constant when aircraft size and flight frequency are changed. Nevertheless, theoretical analyses suggest that these natural monopoly characteristics persist until the schedule becomes "dense." That is, until the benefits of added frequency are exhausted utilizing the most efficient aircraft size. See Panzar, Equilibrium and Welfare in Unregulated Airline Markets, 69:2 AM. ECON. REv. 92 (1979); Dorman, Airline Competition: A Theoretical and Empirical Analysis (unpublished doctoral dissertation, Univ. of Calif. Berkeley 1976).

7. It should be noted, however, that 80 percent of passengers are carried in markets with more than one authorized carrier.

8. See Keeler, supra note 5. 
natural monopoly we hope to focus directly on the issue of workability of competition in markets characterized by increasing returns to scale. By so doing, we hope to convince the reader that, in theory, economies of scale, per se, pose no threat to market efficiency because they do not necessarily result in barriers to entry.

Thus, we subscribe to George Stigler's view of the nature of entry barriers:

A barrier to entry may be defined as a cost of producing (at some or every level of output) which must be borne by a firm which seeks to enter an industry but is not borne by firms already in the industry. ${ }^{9}$

Mere economies of scale, if they reflect the properties of a production process available to all firms, do not fit this definition. It should be noted, however, that this view conflicts with the conventional wisdom in industrial organization which concludes that a falling average cost curve may, in and of itself, constitute a barrier to entry, making it possible to earn supranormal profits without inducing entry. ${ }^{10}$

In a seminal paper, ${ }^{11}$ Harold Demetz challenged this view that economies of scale would, without regulatory intervention, lead to monopoly exploitation. He argued that excess profits would lead to competition for the market rather than competition in the market. If contracting costs were minimal, an entrant could displace the monopolist by offering all of its customers a lower price. The Demetz approach has usually been discussed in a franchise bidding context in which the market is awarded by a governmental authority to the firm offering to serve at the lowest price. Unfortunately, this institutional context obscures the fundamental insight. Despite the fact that Demetz specifically wished to free his analysis of "the theory of natural monopoly . . . from irrelevant complications, such as the durability of distribution systems, . . ."12 much of the subsequent criticism focused on the incentive problems arising from the possibility of having to transfer sunk capital from one franchise to another. ${ }^{13}$ Such problems may be severe or even insurmountable in many practical applications and may well lead to formidable barriers to entry, but it must be recognized that the difficulty arises from the presence of sunk costs, not economies of scale. That capital in place should give rise to entry barriers is not surprising, since such costs, once sunk, do reflect a cost which must be borne by a potential entrant which does not, again, have to be paid by an incumbent. This question is quite distinct from that of economies of scale. ${ }^{14}$

Thus, there is no reason, a priori, to expect that economies of scale should lead to substantial barriers to entry in the airline industry because airline capital costs, while substantial, are not sunk costs. That is, the major portion (i.e., aircraft) can be

9. G. Stigler, The Organization of Industry 67 (1968).

10. See the discussion in F. Scherer, Industrial Market Structure and Economic Performance, ch. 9 (1970). To be fair to the received theory, it should be noted that the actual size of the unit cost penalty paid by small scale operators plays a crucial role in determining the severity of the entry barriers thought to be created by economies of scale. In aviation, this appears to be less severe in pleasure than in business markets. See the evidence from the Miami and Milwaukee based city pair markets presented in Section II, infra.

11. Demsetz, Why Regulate Utilities?, J. L. \& Econ. 55 (1968).

12. Id. at $\mathbf{5 7 .}$

13. See R. Schmalensee, The Control of Natural Monopolies, ch. 5 (1979) for a discussion of this point and a survey of the relevant literature.

14. Baumol \& Willig, supra note 3, fully explore the importance of drawing this distinction. 
"recovered" from any particular market at little or no cost. Such factor mobility makes for ease of potential entry and exit in such markets. Equipment of all sizes, ranging from 6 to 500 seats, is available and there are a variety of potential entrants in each size range of equipment. Potential entrants with equipment that is appropriate to the demand conditions in any particular market, and who have stations at both ends of a city-pair market can readily respond to a potential profit opportunity via entry. This does not mean that a trunk carrier such as Delta Airlines can readily use its L-1011's to enter a commuter market. But Delta can enter a dense long-haul market such as the Los Angeles-New York route using this equipment. Similarly, potential entrants exist for almost all markets, and can enter these markets at the scale that achieves the unit cost advantages attained by the monopolist. Thus, despite substantial natural monopoly attributes, most airline markets are likely to be readily contested. This fact ensures that, even if actually operated by only a single firm, their performance should approach the competitive norm, at least to a tolerable approximation.

This is the theory, or at least our version of it. Our goal in this article is to "test" it using data emerging from the ongoing transition from regulated to unregulated equilibria. In addition to the usual problem created by the unwillingness of the real world to conform to the theoretical postulates of economists, the present effort is also complicated by the fact that the transition has just begun. Moreover, the transition is characterized by a number of residual regulatory and procédural distortions that are discussed in Section II.

In addition, it was clear that the move to deregulation led to an excess demand for aircraft during 1978 and 1979. Because of design and production lags, the short run elasticity of supply of aircraft has been very low. Thus, it is to be expected that individual aircraft were earning quasi-rents during the period we study. Therefore, it is impossible (as well as impractical) to attempt to test competitiveness by such traditional measures as price-cost margins or rates of return during this period. Section III describes how we are able to surmount this difficulty and devise at least a crude test of the market contestability hypothesis using available aggregate price data.

\section{II}

Barriers to Entry in Aviation Markets

In examining evidence about the nature of the barriers to entry in airline markets, it is necessary to make a distinction between barriers which existed prior to airline deregulation and those which may be in effect now. We will argue that there are few, if any, barriers to entry left in domestic United States airline markets.

The United States domestic route system was laid out in 1930 by the Hoover Administration. The predecessors of American, Trans World and United received contracts to carry mail over various multistop transcontinental routings and Eastern was established as the East Coast and Midwest North-South carrier. By the time of the Civil Aeronautics Act of 1938, there were nineteen carriers who were accorded "grandfather" route rights, of whom sixteen began operations. The Civil 
Aeronautics Board (CAB) was entitled to grant additional route authority to existing carriers or to authorize new entry. This authority was exercised differently in different periods. For example, in the mid-1950s, substantial new authority was granted, and local service carriers began to gather strength. In contrast, in the early 1970s little new authority was conferred. Traditional route cases were costly to litigate, requiring a full panoply of written and oral evidence, and often took two years or more to complete.

Starting in 1978, the Board changed its ideas and policy concerning the material evidence required to litigate a case, with neither diversion, profitability nor carrier selection any longer being viewed as issues of material fact that required litigation. Thus, for example, the Board was willing to award route authority to all rather than only a single applicant in a case, even though it recognized that in actuality only one carrier might enter. The Board preferred to let the marketplace, rather than the regulatory agency, do the carrier selection. Nonhearing procedures were also introduced. There was little actual entry in 1978, however, since Board processing of these policies itself took time, and the policies were expected to be litigated in the courts. It was not until the passage of the Airline Deregulation $\mathrm{Act}^{15}$ in October 1978 that entry barriers truly began to topple.

By January 1979, the Board was systematically awarding authority under its new policies. Awards were processed in these multiple permissive entry cases using expedited show cause procedures rather than route proceedings. All requested authority was granted except those at airports with noise or other environmental constraints or to carriers whose fitness was in question. Carriers were not required to exercise their new authority and were permitted to freely exit markets which they were authorized to serve. Only when essential air service at a point has been threatened has exit been delayed. A measure of the speed and pervasiveness of new awards is given in Table III. Table III shows there were 3,189 nonstop route rights granted in the five-month period immediately following deregulation, with another 7,142 route awards pending on February 7, 1979. To put these numbers in perspective, it should be remembered that as of January 1, 1980, there were 2,449 route segments actually flown in the domestic United States market by all certificated air carriers (of these, 1,686 were nonstop route segments flown by the trunk and local service carriers).

The conversion of potential new authority into actual nonstop entry by trunk and local service carriers is illustrated in Table IV. It shows that for a net change of 117 new nonstop services for the trunk and local service carriers between July 1 , 1978, and July 1, 1979, there were 874 actual additions and deletions, with 449 added routes and 332 deletions of nonstop routes. The magnitude of the numbers suggests that with the removal of regulatory barriers to entry, there were few economic barriers to movement.

In this regard, it is well to note that of the 449 new nonstop services, 270 were made between hubs where carriers had a presence before entry in both airports,

15. 92 Stat. 1705 (1978) (codified in scattered sections of 18,49 U.S.C.) 


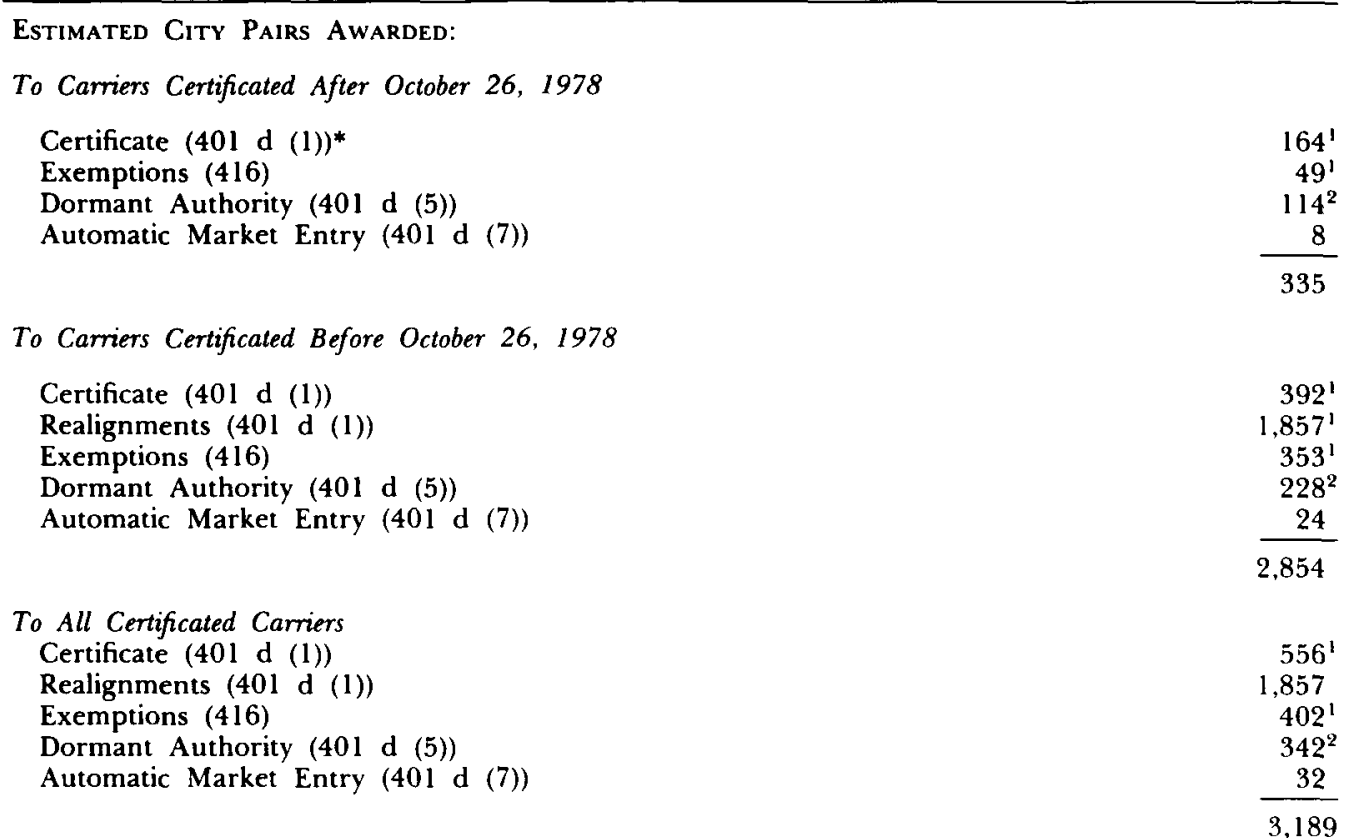

Estimated City Pairs Pending on February 7, 1979:

Formal Certificate Authority

* Refers to section of the Act under which the authority was granted.

${ }^{1}$ Per data filed in the Schedule and Route Information Unit as of April 10, 1979. Includes all nonstop authority awarded. May reflect some slight duplication with existing authority where a carrier received authority between co-terminals on new segments. It was not practicable to remove any such duplication from the study.

${ }^{2}$ As of March 28, 1979.

${ }^{3}$ As of April 10, 1979.

SOURCE: CAB Data.

170 were made between hubs where the carrier had a presence at only one airport and nine were made in cases where the airline had to open new stations at both ends of the city-pair market. Thus, once a carrier has a station at an airport it appears to be relatively easy to start new service into that station.

We turn next to the numbers of carriers who actually serve any particular city-pair market. The number of flights between any two cities is determined by a combination of three factors: economies of scale in aircraft size, which have the effect that there are substantially lower costs per passenger mile the larger the aircraft that is used, density of market demand and the desire of passengers to fly 
TABLE IV

New Nonstop Service by Size of Carrier JULy 1, 1978 TO JULY 1, 1979

\begin{tabular}{lccc}
\hline & Additions & Deletions & Net \\
Five Large Trunks & 172 & 173 & -1 \\
Small Trunks & 132 & 82 & 50 \\
Local Service & $\frac{145}{449}$ & $\frac{77}{332}$ & $\frac{68}{117}$
\end{tabular}

Five Large Trunks: American, Delta, Eastern, Trans World, United.

Small Trunks:

Local Service:

Braniff, Continental, National, Northwest, Pan American, Western.

Frontier, Hughes Airwest, Ozark, Piedmont, Republic, Texas International, US Air.

SOURCE: CAB Analysis of Offical Airline Guide data.

at particular times of day. Table $\mathrm{V}$ displays the number of nonstop and one-stop domestic flights into two U.S. hub airports ${ }^{16}$-Miami and Milwaukee-as of January 1, 1980. Miami is an airport with a large volume of discretionary traffic; Milwaukee is an airport catering mainly to the business traveler. Of eighty-eight city-pairs with nonstop or one-stop service into Miami by carriers of all sizes (including commuters), thirty-two markets had only a single flight per day. There is a similarly large percentage of single flight markets into Milwaukee. Thus, the evidence suggests that it is economic to serve markets even if only one flight per day in each direction is offered. Of the seventeen markets with two flights per day into Miami, nine were served by two carriers; of twenty-five markets with five or more flights per day, twenty-three were served by four or more carriers. In contrast, Milwaukee displays a larger proportion of city-pair markets which offer services by only a single carrier. Thus, the proportions of multiple carrier markets are higher in the pleasure hub. Moreover, a close look at the multiple carrier markets from both cities reveals that such markets are likely to have one or more end points that are either large hubs or pleasure markets. Multiple carrier services thus seem to predominate when carriers can combine discretionary with business travel. The greater flexibility of the discretionary traveler (less concern about time of departure, less concern about last minute seat availability) creates an opportunity for exploitation of joint costs in pricing. Overall load factors can then be made sufficiently high that more than one carrier finds it remunerative to enter. Thus, competition for the market, rather than in the market, is a common occurrence in aviation.

The chief sunk cost in aviation is the cost of airport plant-runways, towers, and ground facilities. These costs are incurred by municipalities rather than airlines. In practice, however, municipalities often bind particular airlines under long-term

16. Airports are classified by number of enplanements per year into 24 large hubs, 33 medium hubs, and 86 small hubs. In total, these hub airports enplane about 95 percent of U.S. domestic passengers. Several hundred nonhub airports enplane the remaining 5 percent of passengers. 
TABLE $\mathbf{V}$

City-Pair Markets to Miami and Milwaukee JANUARY 1,1980

\begin{tabular}{crcccc}
\hline Number of Carriers & \multicolumn{5}{c}{ Number of Flights into Hub Per Day } \\
& 1 & 2 & 3 & 4 & $5+$ \\
Miami, 88 Markets & 32 & 8 & 1 & 1 & 1 \\
1 & & 9 & 6 & 2 & 2 \\
2 & & & 2 & 1 & 11 \\
3 & & & & \\
$4+$ & 18 & 11 & 8 & 3 & 4 \\
Milwaukee, 61 Markets & & 3 & 5 & 5 \\
1 & & & & 1 \\
2 & & & & 1 \\
$4+$ & & & & \\
\hline
\end{tabular}

Source: CAB Analysis of Official Airline Guide data.

lease and other arrangements to underwrite the sunk costs of their airports. This practice leads to a market imperfection at airports in which carriers can determine when, and if, and at what price, to sublease to their competitors. In the limit, if a single carrier has a long-term lease on all the gate space at an airport, that carrier is likely to either block all new entry or to extract monopoly rents from any new entrant to which it subleases. The problem is illustrated by Laker Airways' search for gate and terminal space at Kennedy Airport. Because the international terminal, which is owned by the Port Authority, was full, Laker contacted various airlines with no success despite the fact that at least one terminal, National's, had unused space throughout this period. Laker was unable to get help from the Port Authority. So Laker had to ticket on Queens Boulevard in Long Island and bus its passengers and their luggage to Kennedy. In the more usual case, there is excess gate capacity and a number of carriers serving at an airport, this develops an active sublease market for new entrants seeking gate space.

A second concern at airports is the type of market power that has been and is being exercised by airport authorities because of noise or environmental constraints. Recently, the San Diego Airport attempted to ban all new entry while allowing incumbent carriers to expand their operations at will. Obviously, this rule does not result in optimal noise reduction for a given number of flights and discriminates against newcomers. Burbank Airport has adopted a cumulative noise ceiling and contends that it has the authority to reject any proposed new service by a new entrant or an incumbent even if the new service would not bring the noise level above the ceiling. Orange County Airport engages in similar practices. At present, three of the five airports in the Los Angeles basin have adopted extraordinarily restrictive limits on airport access, and as a result the burden placed on the two remaining facilities is provoking efforts to cap their growth. Many other airports in the West also either have or may soon have binding environmental or noise constraints. These types of market imperfections were responsible in part for 
the Board's decision in September 1979, not to permit the merger of two primarily western United States-based airlines, Continental and Western. ${ }^{17}$

A third market imperfection that occurs at airports relates to slot and fuel allocations. For example, slot allocations are now imposed at four major airports, National, O'Hare, LaGuardia and Kennedy, and may be needed at eight or nine more airports between now and 1989. Since 1968, when the Federal Aviation Administration's (FAA) high density airport rule took effect, the CAB has granted antitrust immunity to the airlines to meet and allocate among themselves the available slots according to a rule of unanimity. The Board and the FAA are now discussing less anticompetitive and nondiscriminatory solutions to overcome these market imperfections at airports. The long-term lease arrangements are being reviewed and their potentially discriminatory effects studied. A variety of approaches to meeting environmental concerns that do not require discrimination against a particular class of airline are being explored. The Board and the FAA commissioned a study by the Polinomic Research Laboratories of alternative methods for slot allocation. The airlines themselves are also actively seeking to get around those aspects of the restrictions that bind them by using, for example, the automatic market entry provisions of the Airline Deregulation Act. In 1980, all but eleven of forty-eight automatic market entry requests involved airports that had noise, environmental or slot constraints.

Finally, there appears to be a networking scale economy at airports. Delta and Eastern, for example, have a strong duopoly position at Atlanta Airport that cannot be duplicated by a new competitor. Their large volume of connecting flights offers a quality of service to travelers that other carriers cannot match. Only when further market growth means that nonstop services can replace one-stop services through Atlanta will this market indivisibility be mitigated.

In spite of these various market imperfections at airports, it appears that entry of airlines at airports has been fairly fluid. For example, there were 100 cases of new entry by the trunk and local service carriers into the 143 hub airports in the United States as measured on July 1, 1979 versus July $1,1978 .^{18}$

In sum, with the exception of specific environmental, noise and local factors at some airports, virtually all of the significant legal barriers to new entrants have been removed.

\section{III}

\section{Pricing Policy and Potential Competition}

In domestic United States aviation markets, explicit price competition was not encouraged until 1977 when downward pricing flexibility was granted. As formalized by the Board, ${ }^{19}$ the zone permitted fare flexibility down to 50 percent of standard fare levels without justification and 70 percent below with respect to 40 percent of a carrier's weekly available seat-miles. The Airline Deregulation Act has

17. See the Continental-Western Merger Case, CAB Order 79-9-185.

18. CAB Analysis of Official Airline Guide Data.

19. See CAB Rule PS-80. 


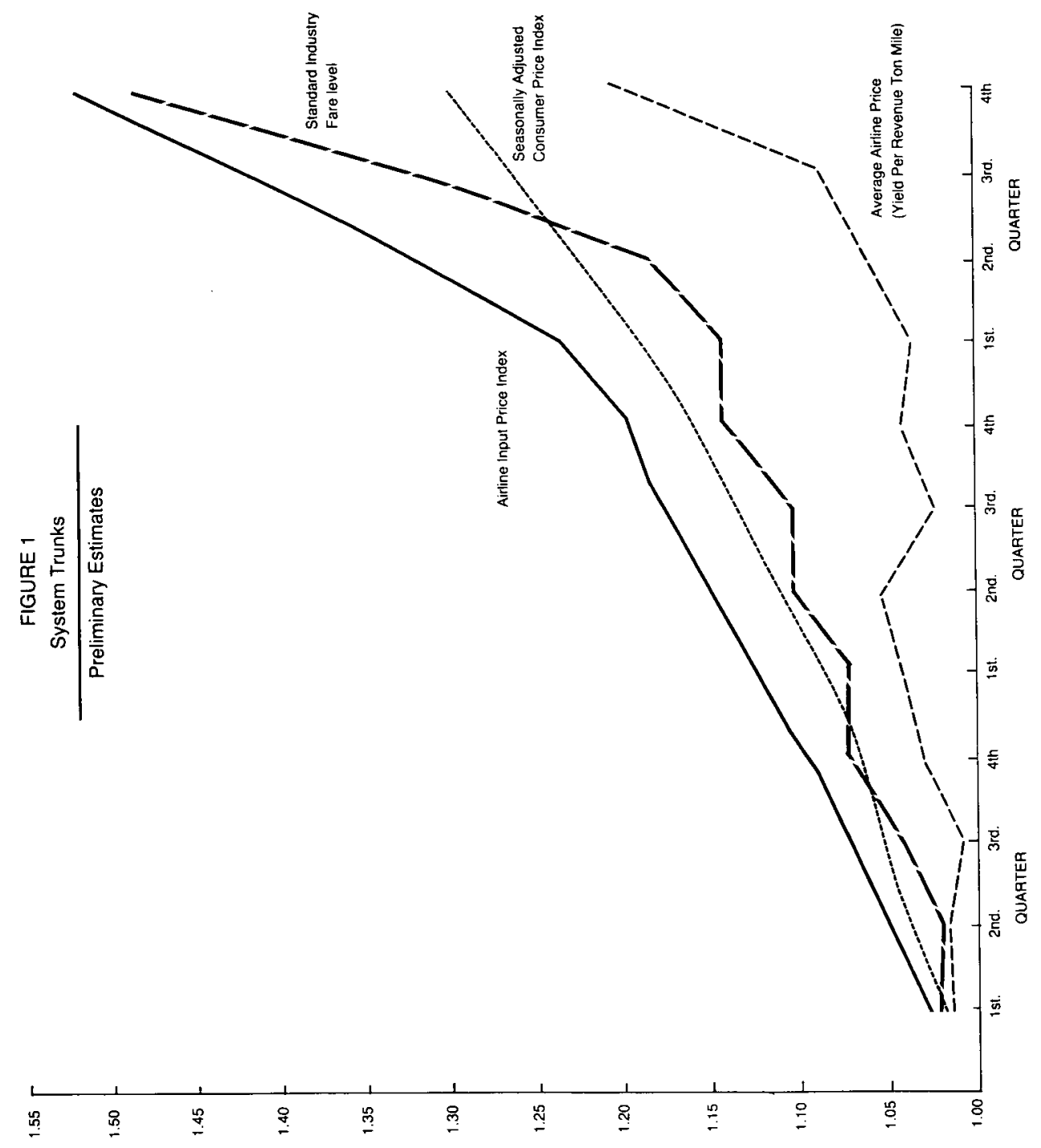


a similar zone of downward fare flexibility. This policy has resulted in a situation over the last few years where there has been a growing disparity between the normal economy fare and the average fare paid by the traveling public. As Figure 1 shows, the standard coach fare (denoted as Standard Industry Fare Level on the Figure) and average coach fare were about equal in the first and second quarters of 1977, just before the CAB changed its policy toward discount fares. Thereafter, substantial numbers of passengers began traveling at discount fares and a number of markets came into being with low unrestricted fares. Thus, average fare has recently been substantially below standard coach fare.

Upward pricing flexibility has been circumscribed both by Board policy and by the Airline Deregulation Act. A price ceiling was established under the Airline Deregulation Act that is based on the formula established in Phase 9 of the Domestic Passenger Fare Investigation (DPFI) ${ }^{20}$ The DPFI formula set equal rates for flights of equal distance based on industry average costs, a set load factor, and a mileage formula with a cost taper requiring lower per mile fares for longer haul flights. The Airline Deregulation Act based its ceiling on fares in effect on July 1 , 1977. Under CAB policy set out in August $1978,{ }^{21}$ trunk carriers in workably competitive markets (defined as those with four or more carriers authorized) were allowed to raise their fares up to 10 percent above the ceiling. In markets with fewer carriers authorized, carriers were given the flexibility to raise fares up to 5 percent above the ceiling for a limited number of days per year. This was meant to provide an incentive for carriers to use peak/off-peak pricing. The Airline Deregulation Act permitted 5 percent upward fare flexibility for routes served by nonmonopoly carriers (defined as carriers which provide air transportation to less than 70 percent of the air passengers between a pair of points). The computation of the Standard Industry Fare Level (SIFL) under the Airline Deregulation Act is updated periodically by the percentage change in operating costs per available seat-mile. It should be emphasized that while the DPFI/SIFL ceiling does have cost pass throughs, it was not geared to inflation pricing, and the Board is still having to adjust its techniques and timing to cope with the current spiraling costs.

One final piece of information about the DPFI is that the fare formula has been known for some years to underprice short-haul service (mileage bands below 400 miles) and to overprice long-haul service. Since local service carriers had average stage lengths of about 200 miles, they were permitted to price at a ceiling based on 130 percent of DPFI fares. This 130 percent ceiling was, however, applied to all local service routes, no matter what their stage length. The locals had a number of long-haul markets by 1978, and expanded into many others after the passage of the Airline Deregulation Act in October 1978. The locals can price any of these markets at 130 percent of DPFI, and in markets in which they were at the 130 percent ceiling on July 1, 1977, they have the additional 5 percent upward fare

20. CAB Docket 21866-9. Domestic Passenger-Fare Investigation Phase 9-Fare Structure Order 75-12-33 (Dec. 5, 1975).

21. CAB Rule PS-80. 
flexibility granted under the Airline Deregulation Act. The different treatment of the price ceiling for the trunks and for the local service carriers has caused a regulatory window that permits us to make (at least crude) inferences about the effectiveness of potential competition.

Finally, the Airline Deregulation Act mandated that the Board extend joint fares to commuter carriers, which resulted in substantial portions of short-haul ticket prices being paid by trunk and local service carriers to the commuters. For trunk carriers, the combination of an underpriced fare ceiling in short-haul markets and the mandatory joint fares meant that there was a strong incentive to exit these markets. Table VI displays this net exit of the trunks in the low mileage blocks as well as the net entry of both trunk and local service carriers into routes with stage lengths over 600 miles.

TABLE VI

Usable Nonstop Service Additions (Deletions) OCTOBER 1978 TO OCTOBER 1979

\begin{tabular}{ccc} 
Mileage Block & Trunks & Locals \\
$0-200$ miles & $(34)$ & $(7)$ \\
$201-400$ miles & 1 & 7 \\
$401-600$ miles & 13 & $(5)$ \\
601 Plus & 76 & 28 \\
\hline
\end{tabular}

Source: CAB Data.

TABLE VII

Comparison of SIFL and Actlal Yields by Mileage Block Trunks and Locials, Third QLarTer 1979

\begin{tabular}{|c|c|c|c|c|c|}
\hline \multirow[t]{2}{*}{$\begin{array}{l}\text { Mileage Block } \\
\text { Midpoint }\end{array}$} & \multirow[t]{2}{*}{$\begin{array}{c}\text { SIFL } \\
\text { Fare/Mile }\end{array}$} & \multicolumn{2}{|c|}{$\begin{array}{l}\text { Markets With One } \\
\text { Carrier Authorized }\end{array}$} & \multicolumn{2}{|c|}{$\begin{array}{c}\text { Markets With More Than } \\
\text { One Carrier Authorized }\end{array}$} \\
\hline & & Overall Average & Coach & Overall Average & Coach \\
\hline 100 & 31.68 & 29.54 & 30.67 & 23.61 & $24.31^{3}$ \\
\hline 200 & 21.44 & $18.83^{2}$ & 21.37 & 19.75 & 19.80 \\
\hline 300 & 18.03 & 17.08 & 18.31 & 15.46 & 16.19 \\
\hline 400 & 16.32 & 14.92 & 15.84 & 13.17 & 13.95 \\
\hline 500 & 15.30 & 13.17 & 14.50 & 13.13 & 14.50 \\
\hline 700 & 13.37 & 11.33 & 12.68 & 11.17 & 11.24 \\
\hline 1000 & 11.92 & 9.95 & 11.68 & 9.18 & 10.76 \\
\hline 1300 & 11.14 & 9.34 & 10.90 & 9.19 & 10.55 \\
\hline 1600 & 10.63 & 9.11 & 10.59 & 8.46 & 9.93 \\
\hline 1900 & 10.25 & 7.67 & 9.63 & 8.00 & 9.88 \\
\hline 2200 & 9.97 & 8.25 & 9.24 & 7.61 & 8.99 \\
\hline 2500 & 9.76 & 7.20 & 9.57 & 7.02 & 8.87 \\
\hline \multicolumn{6}{|c|}{$\begin{array}{l}1 \text { Formula: } .2048 \notin+.1120 \propto(0-500)+.0854 \notin(501-1500)+.0821 \notin(1501+) \text {. } \\
2 \text { This figure would be raised to } 20.60 \text { if we excluded the Honolulu-Hilo market. } \\
3 \text { This figure would be raised to } 27.47 \text { if we excluded the Los Angeles-San Diego market, where } \\
\text { ompetition with intrastate carriers resulted in extremely low fares. }\end{array}$} \\
\hline
\end{tabular}

Source: CAB Data.

With this background, it is useful to look at an aggregate view of overall coach fares per mile and actual yields (including first-class fares) per revenue passenger 
mile. These figures are presented in Table VII, broken down by mileage bands, for monopoly markets in which only one carrier is authorized, and for all other markets (monopoly markets with more than one carrier authorized and competitive markets). Analysis reveals that the mean level of coach fares is at 97 percent of SIFL in markets with only one carrier authorized in contrast to 90 percent of SIFL in markets where actual or potential entry is possible. Thus, prices are higher where entry is precluded.

Perhaps the most striking aspect of these summary statistics is that despite the existence of unrestricted coach fares in a number of highly publicized markets, overall coach fares are very near the ceiling levels.

This is in part due to some regulatory lag in passing through fuel cost increases to the carriers in the summer of 1979. It is also in part due to the fact that trunk carriers have tended to price compete via discount fares and other promotions, such as coupons, rather than through differentials in normal economy fares.

Table VIII displays the pricing behavior of carriers in nonstop monopoly markets of from 1-200 miles. Data on commuter carriers indicates that for the year ending June 30, 1979, commuter carriers participated in 96 percent of on-line traffic moving in city-pair markets in the $0-49$ mileage range, in 77 percent of traffic in the 50-99 mileage range, in 35 percent of the traffic in the 100-149 mileage range and in 15 percent of the traffic in the 150-199 mileage range. A

TABLE VIII

Comparison of SIFL and Tariff Fares January 1, 1980 of Certificated and Commuter Carriers

\begin{tabular}{|c|c|c|c|}
\hline \multirow[b]{2}{*}{ Percent Tariff Above SIFL } & \multicolumn{3}{|c|}{$\begin{array}{c}\text { Nonstop Monopoly Markets } 0-200 \text { Miles } \\
\text { Number of Markets }\end{array}$} \\
\hline & $\begin{array}{c}\text { Trunk } \\
\text { Carriers }\end{array}$ & $\begin{array}{l}\text { Local Service } \\
\text { Carriers }\end{array}$ & $\begin{array}{c}\text { Commuter } \\
\text { Carriers }\end{array}$ \\
\hline $\begin{array}{l}35.0 \% \text { or More } \\
30.0 \text { to } 34.9 \%\end{array}$ & & $\begin{array}{r}2 \\
87\end{array}$ & $\begin{array}{l}5 \\
8\end{array}$ \\
\hline 25.0 to $29.9 \%$ & & 124 & 12 \\
\hline 20.0 to $24.9 \%$ & I & 26 & 20 \\
\hline 15.0 to $19.9 \%$ & & 58 & 7 \\
\hline 10.0 to $14.9 \%$ & & 13 & 17 \\
\hline 5.0 to $9.9 \%$ & 21 & 5 & 12 \\
\hline 0 to $4.9 \%$ & 21 & 7 & 8 \\
\hline Tariff $=$ SIFL & 21 & 22 & 9 \\
\hline \multicolumn{4}{|l|}{ Percent Tariff Below SIFL } \\
\hline 0 to $4.9 \%$ & & 2 & 11 \\
\hline 5.0 to $9.9 \%$ & & & 9 \\
\hline 10.0 to $14.9 \%$ & & & 3 \\
\hline 15.0 to $19.9 \%$ & & & 3 \\
\hline 20.0 to $24.9 \%$ & 1 & 14 & 10 \\
\hline 25.0 to $29.9 \%$ & & & 5 \\
\hline 30.0 to $34.9 \%$ & & & 7 \\
\hline $35.0 \%$ or More & - & & 11 \\
\hline Total & 65 & 360 & 157 \\
\hline
\end{tabular}

SOURCE: CAB Data. 
ranking of commuter prices in markets in which commuters are providing the only nonstop service indicates that while they have complete pricing flexibility, they are not charging fares above the ceiling levels permitted the local service carriers. Indeed, their fares are widely dispersed suggesting that that fare structure is heavily constrained by potential competition not only from local service carriers, but also from alternative modes of transportation such as bus, train and automobile.

The local service carriers display more ability to price near the ceiling fares permitted them, with a large number of their normal economy fares being in the upward end of their permitted range. This reflects, in part, their ability to offer a full range of price options to travelers unlike the commuters who generally offer only a single fare. ${ }^{22}$ Even for the locals, however, there are a number of markets which are priced below the ceiling fare, a clear indication that factors other than CAB fare regulation are constraining local carrier fares. The trunks are not entering many short-haul markets; thus, they do not serve as potential entrants into these markets.

The results from the commuter industry along with the dispersion evident for the locals both played a part in a recent $\mathrm{CAB}$ decision to lift the price ceiling for short-haul markets. By so doing, the Board hoped to stem the loss of jet services by permitting carriers to raise prices to a level that would be compensatory ${ }^{23}$ and to offer the public a choice between (perhaps) higher priced jet service and the services of the commuters.

Table IX displays the distribution of fares for longer haul mileage bands. In the 201-400 mileage block, the normal economy fares of the local service carriers are often higher than the 5 percent upward flexibility permitted trunk carriers. These data are consistent with the proposition that the SIFL formula understates carrier costs in the short-haul markets at least well into the 201-400 mileage block. Thus, potential competition of trunk carriers is not sufficiently likely that locals feel constrained by it.

The dramatically smaller percent of tariffs substantially above SIFL for the longer haul routes of the locals is consistent with the efficacy of potential competition in routes that are attractive to trunk carriers. These routes are attractive to locals who can now "feed" themselves rather than turning their traffic over to the trunks. The data also suggest that the ceiling may be constraining the trunk carriers who in general appear to have taken what upward price flexibility is available to them. Markets which are not priced at the ceiling are either particularly

22. This discrepancy in behavior is caused in part by the Board's mandatory joint fare program, under which commuters disproportionately benefit from the divisions of revenues mandated for the normal economy fare. The trunks and locals have refused to offer joint fares with commuters on their APEX and other discount fares, to avoid dilution of revenues on these fares.

23. It has been argued by the CAB's Office of Economic Analysis that the very stringent price ceiling in California has stimulated disproportionate exit by trunks in that state. Price ceilings are lower in California than elsewhere because as of July 1, 1977 state price regulations had held prices well below the DPFI levels that were in effect for the rest of the country. See December 11, 1979 CAB memorandum entitled "What Should Board Policy be With Respect to Intra-California Fares." 
TABLE IX

Comparison of SIFL and Tariff Fares January 1, 1980

NONSTOP MONOPOLY MARKETS

\begin{tabular}{|c|c|c|c|c|c|c|}
\hline \multirow[b]{2}{*}{ Percent Tariff Above SIFL } & \multicolumn{2}{|c|}{ 201-400 Miles } & \multicolumn{2}{|c|}{$401-600$ Miles } & \multicolumn{2}{|c|}{601 Plus Miles } \\
\hline & \multicolumn{2}{|c|}{ Number of Markets } & \multicolumn{2}{|c|}{ Number of Markets } & \multicolumn{2}{|c|}{ Number of Markets } \\
\hline $\begin{array}{l}35.0 \% \text { or More } \\
30.0 \text { to } 34.9 \%\end{array}$ & $\begin{array}{l}1 \\
1\end{array}$ & $\begin{array}{r}3 \\
19\end{array}$ & & & & \\
\hline 25.0 to $29.9 \%$ & & 49 & & 1 & & 1 \\
\hline 20.0 to $24.9 \%$ & & 22 & & 2 & 2 & 1 \\
\hline 15.0 to $19.9 \%$ & & 31 & & 3 & 5 & $i$ \\
\hline 10.0 to $14.9 \%$ & 1 & 16 & 1 & 4 & 38 & 3 \\
\hline 5.0 to $9.9 \%$ & 29 & 22 & 71 & 4 & 108 & 26 \\
\hline 0 to $4.9 \%$ & 37 & 13 & 49 & 22 & 21 & 4 \\
\hline Tariff $=$ SIFL & 33 & 8 & 29 & 10 & 52 & 11 \\
\hline \multicolumn{7}{|l|}{ Percent Tariff Below SIFL } \\
\hline $\begin{array}{r}0 \text { to } 4.9 \% \\
5.0 \text { to } 9.9 \%\end{array}$ & 5 & $\begin{array}{l}1 \\
3\end{array}$ & & 4 & 20 & 1 \\
\hline 10.0 to $14.9 \%$ & & & & & 1 & \\
\hline 15.0 to $19.9 \%$ & & & & & & \\
\hline 20.0 to $24.9 \%$ & & & & & & \\
\hline 25.0 to $29.9 \%$ & & & & & & \\
\hline 30.0 to $34.9 \%$ & & & & & 1 & \\
\hline $35.0 \%$ or More & & & & & 6 & \\
\hline Total & 107 & 187 & 150 & 50 & 254 & 48 \\
\hline
\end{tabular}

SOURCE: CAB Data

competitive ones (routes to Las Vegas, Miami, etc.) or are served by low cost carriers.

This legal ability of the local service carriers to raise fares above the ceiling level applicable to trunks allows us to make some important inferences which, while hardly conclusive, are at least consistent with the theory we wish to test. The logic of our argument is as follows:

Assume that the fare ceilings are in fact binding in this set of markets. Assume also that the markets involved are similar in the sense that there is enough uniformity of available equipment types, realizable load factors, ability to price discriminate, etc., so that the relationship between fare level and the SIFL can be taken as at least a crude proxy for the quasi-rents earned by (economically scarce) aircraft operating in those markets. Then, if markets are readily contestable, the free movement of aircraft between markets should result in an equilibrium with a fare at the ceilings specified under the Airline Deregulation Act. Since this ceiling is higher for locals, their fares would be expected to equilibrate at a higher percentage of SIFL, were it not for the potential competition of trunks.

Indeed, in longer haul markets local service monopolists do, in fact, seem to price around the ceiling allowed to trunks (72 percent of those in the 401-600 mileage band; 85 percent in the 601 + category). Presumably, fear of competition from trunks keeps prices from being higher, but what causes them to cluster around the trunk 
ceiling? That is, since there is no binding floor on what the trunks can offer, why isn't it necessary to price even lower to prevent entry by trunks? The most satisfying answer we have been able to come up with squares nicely with a theory of short run equilibrium in contestable markets. Until this winter, there has been a supply constraint in all aircraft (this constraint still exists for small aircraft). The trunks have allocated their scarce equipment to equalize returns at the margin, said margin being (very) roughly characterized by 105 percent of SIFL in January 1980. Because of this implicit opportunity cost, trunks have an incentive to enter only those markets promising greater profits. Thus, local monopolists in thin longer haul markets need fear trunk entry only if they price above the trunk ceiling.

In the short-haul (201-400 miles) markets local monopolists succeeded in elevating prices above the trunk ceiling 75 percent of the time. This reflects in part the understatement of short-haul costs discussed above. It also may reflect additional quasi-rents earned by equipment owned by locals which is especially well suited to this length of haul. Equipment availability may also account for the relative lack of effective potential competition from unregulated commuter airlines. For years, the "regulatory threshold" was thirty seats or less; that is, firms operating aircraft of thirty seats or less were unregulated, those operating aircraft with more than thirty seats were subject to $\mathrm{CAB}$ regulation. This resulted in aircraft being designed either to meet that constraint or be large enough for more general system use. This seems to have led to a "gap" in the size distribution of available aircraft, so that relatively few were designed to specifically and efficiently serve moderately dense markets with this length of haul.

The most convincing evidence concerning the efficacy of potential competition comes from a regression analysis conducted by Daniel Kaplan of the Board's Office of Economic Analysis and described in a notice of proposed rulemaking, ${ }^{24}$ which resulted recently in the grant of further upward pricing flexibility to the industry. Table $\mathrm{X}$ displays his results. The regression is made on a sample of forty-three markets served by local service carriers which range in length from 85 miles to 778 miles, and which contain both monopoly and competitive markets. ${ }^{25}$ The dependent variable is the local carrier's fare in the December 15, 1979 Official Airline Guide divided by the SIFL fare at that time. Two factors that could effect fare levels in markets are considered: distance and the presence of competitive carriers. Markets are grouped by mileage blocks of 100 miles, $0-100,101-200, \ldots 601-700$. There are also variables which signal the presence of trunk competition in markets less than 400 miles, the presence of trunk competition in markets greater than 400 miles, and the presence of competition from another local service carrier or a commuter carrier.

The constant term (or reference fare) in Table $\mathrm{X}$ is the estimate of fare level in markets above 700 miles where there are no competitors present. It is seen that the fare is .988 times the DPFI fare. This is consistent with our earlier evidence about

24. See CAB, PSDR-66.

25. In those cases where there was more than one local service carrier, the fare of the carrier with the most departures was used. 
TABLE $\mathrm{X}$

Regression Analysis

FEBRUARY 1980

\begin{tabular}{|c|c|c|c|}
\hline \multirow{2}{*}{$\begin{array}{l}\text { Dependent } \\
\text { Variable }\end{array}$} & \multirow{2}{*}{$\frac{\text { S Fare })}{\text { DPFI Fare) }}$} & \multicolumn{2}{|c|}{ December 15, 1979 Official Airline } \\
\hline & & \multicolumn{2}{|c|}{ Guide Data, Local Service Carrier Fare } \\
\hline \multirow[t]{13}{*}{ Mean 1.12499} & $\mathrm{R}^{2}=.4320$ & & \\
\hline & Dummy Variables & Coefficient & $T$ \\
\hline & Constant & .988 & 14.4 \\
\hline & $<100$ & .224 & 2.6 \\
\hline & $101-200$ & .198 & 2.6 \\
\hline & $201-300$ & .195 & 2.5 \\
\hline & $301-400$ & .215 & 2.6 \\
\hline & $401-500$ & .057 & .8 \\
\hline & $501-600$ & .072 & .7 \\
\hline & $601-700$ & .023 & .3 \\
\hline & Comp. Trunk $\leqslant 400$ & -.157 & -4.1 \\
\hline & Trunk $>400$ & -.012 & -0.2 \\
\hline & Other Comp. & .030 & 0.9 \\
\hline
\end{tabular}

SOURCE: CAB's Office of Economic Analysis.

coach fares from Table VII. Fares in other types of markets are calculated by adding the coefficient values of the relevant variables to the reference value. For example, to estimate the fare in a market of 150 miles with no competitors present, we add the coefficient value of .198 to .988 , which yields an estimate of the fare in that market as 1.186 times the DPFI. The high " $T$ " statistic for this coefficient along with its large size assures us that we can be reasonably sure that this fare level is greater than the reference fare level. Indeed, fares in all local service monopoly markets of less than 400 miles are seen to be above the reference level.

The low " $T$ " statistics for markets longer than 400 miles and the small size of the coefficient indicate that we cannot be sure the coefficient is different from zero. The regression thus indicates that, controlling for the existence of competition, local carrier fares in markets less than 400 miles are significantly above SIFL levels while fares in markets greater than 400 miles are not. Stated differently, local service carriers are using their upward fare flexibility in markets less than 400 miles, but are not using it (at least to the same extent) in markets greater than 400 miles.

The effect of the existence of a competitor on the fare in a market can be calculated by adding the coefficient values of the relevant variables to the estimate. For example, if a trunk competitor is present in a 150-mile market, we add -.159, the coefficient value of trunk competition, to the earlier estimate of 1.186. Thus, the estimate of the local service carrier's fare in a market of 150 miles with a trunk competitor is $1.027(1.186-.159)$ times the DPFI fare. Statistically, this result is significant. Thus, we have supporting evidence that the pricing behavior of locals is different in short-haul markets where they face actual trunk competition than it is 
in short-haul markets where actual competition is absent. In particular, in markets below $\mathbf{4 0 0}$ miles, the presence of a trunk carrier means fares are 15.9 percentage points lower than they are in a monopoly market of similar length. The presence of a commuter or another local service carrier has a slightly positive but statistically insignificant effect on fares.

These findings are consistent with the view that actual competition of trunks was, at this time, an effective check on the pricing policies of local service carriers in mileage bands under 400 miles, while potential competition was the check in mileage bands over 400 miles. Potential competition between locals or between locals and commuters was not an effective check on the pricing policies of the locals. There were few locals competing (only three instances in our sample) because there was still not much overlap in their markets. There were eleven markets with commuter carrier competition. But the gap in perceived quality of service (jets versus commuter aircraft) meant that commuters were not perceived by locals as potential entrants of sufficient stature to cause them to lower their prices.

The importance of these results can be better appreciated by adopting the vantage point of local service carriers with respect to their relative market positions. Their long-haul markets could be served with but a tiny fraction of aggregate trunk capacity. This large fleet must be regarded as a mobile force of potential "entrants," able to rapidly respond to profitable opportunities, without risking much in the form of sunk costs. The only way for the locals to deter such entrants is by pricing down to these entrants' opportunity cost of capacity, which at this time was (roughly) represented by 105 percent of SIFL, the rate which, on average, the trunks were able to achieve elsewhere. The fare would not fall much lower should a trunk and local actually end up competing head-to-head, because if it did, one or the other would have an incentive to reallocate its aircraft elsewhere. This is precisely what the regression results indicate. Fares in long-haul local markets $(601+$ miles) are approximately equal to the ceiling fares regardless of whether or not the local carrier faces trunk competition. The picture is different in shorter haul local markets. The rather specialized equipment requirements do not make these as vulnerable to entry by trunks. That is, unlike the case in local service long-haul markets, the equipment required to serve local service short-haul markets is not a trivial portion of the total available suitable equipment. Thus, no vast pool of mobile capacity (of the right type) can be relied upon to discipline the market. And we find, in fact, that local carriers are able to elevate their fares substantially above SIFL markets under 400 miles, in the absence of actual trunk competition. (This is also due, in part, to the fact that SIFL significantly underestimates costs in such markets.) Notice, however, that the presence of a trunk competitor has the effect of driving the fare down (by about sixteen percentage points) toward the trunk ceiling level. Actual competition proves to be an effective check even when potential competition does not.

However, we must point out that while trunks can readily enter local service markets with substantial capacity, locals and other small certificated carriers cannot provide the capacity or wide-body equipment required to discipline trunk markets. 
Low fare competition for trunk markets has come mainly from new entrants, such as World, Southwest, and Air Florida. When these carriers have sufficient capacity for a market, such as Southwest's entry into the Dallas to New Orleans market, they can readily gain market dominance. But often these carriers have only a small amount of capacity and their capacity is not aways sufficient to make matching worthwhile. Thus, for example, Air Florida's entry into the Northeast United States to Florida market did not elicit matching behavior by the incumbent trunk carriers. There was matching of World Airway's coast-to-coast prices in the summer of 1979. But this is thought to be largely attributable to United's wish to rebuild its traffic quickly after its strike. It was not surprising that prices rose when World went on strike and then to see that the trunks did not match when World finally reentered the market in February 1980. It was only when Eastern entered with substantial capacity that a serious contest for the market began to take place. Thus, potential competition is not yet the potent force for trunk carriers that it is for the locals.

Moreover, the airline industry is still in a time of strong transition. Fuel prices increased over 100 percent from mid-1979 to mid-1980 and an economic recession began in early 1980. These two circumstances have adversely affected the demand for air travel and the earnings of the air transport industry. Because the cost of car transportation has risen even more than the cost of air transportation, ${ }^{26}$ the demand for short and medium-haul services is still relatively strong. Thus, the local service carriers are faring relatively well. However, demand for longer haul services and for services to and from the regions most heavily affected by the recession is down in many instances, and a number of trunk carriers are beginning to announce serious cut backs in service.

In order to ease the situation, in the late spring of 1980 the CAB substantially increased upward fare flexibility for the industry and removed the difference in fare ceiling treatment for trunks and for local service carriers. Under the newly issued interim domestic fare flexibility policy, ${ }^{27}$ all carriers now have a 130 percent ceiling on routes of more than 400 miles, a 50 percent ceiling on routes between 201-400 miles and complete pricing freedom on routes between 0 and 200 miles. Clearly, analysis will continue to be needed if we are to monitor fully the degree of contestability in different markets and in different regions of the country during this next phase of transition. The dilemma facing the CAB is that the current disequilibrium conditions may, in the short run, result in relatively high prices for some markets, namely those which have an insufficient supply of potential new entrants at the origin and destination airports. Yet, protection of prices in such markets may not be the solution. For the very highness of the prices may serve an important role as a signal for new entry. In any event, it is not at all clear that the long-haul thin markets served by trunks are at present subject to the same competitive check that our results have shown for the locals.

26. See April 22, 1980 CAB memorandum from Roy Pulsifer entitled, The Effect of Relative Prices on Domestic Airline Traffic in 1980.

27. CAB, PS-92 and 94, Docket 37982. 


\section{Summary}

We cannot claim to have done an exhaustive empirical analysis of airline markets in transition. However, we do feel that the admittedly scanty evidence during the first year after deregulation is consistent with our theory that airline markets are basically contestable and we hope to have convinced the reader that it is possible to shed some light on what is, by definition, a postulate about long run equilibrium using data generated during a rather brief period of time.

We wish to leave the reader with the following message: In a perfectly contestable natural monopoly market, actual entry is redundant. The mere threat of entry will discipline the market even if it is a natural monopoly. We have argued that long haul airline markets served by local service carriers most closely fit this theoretical ideal. The empirical evidence of late 1979 and early 1980 does, in fact, bear us out. Local service monopolists have been pricing more or less competitively on their long-haul routes. 
